\author{
MAREK SMOŁA* \\ Tarnów \\ ORCID: 0000-0002-0182-6256
}

\title{
PROBOSZCZOWIE PARAFII ŚW. WAWRZYŃCA W BIEGONICACH W OKRESIE STAROPOLSKIM. PRZYCZYNEK DO DZIEJÓW DUCHOWIEŃSTWA SĄDECCZYZNY
}

Parafia św. Wawrzyńca jest współcześnie najstarszą czynną w Nowym Sączu i jedną z najstarszych na terenie Sądecczyzny. Parafia św. Małgorzaty, związana później z kapitułą kolegiacką, została erygowana dopiero w I292 roku ${ }^{\mathrm{I}}$. Najpewniej w XV stuleciu powstała parafia (nie funkcjonująca między XVI a XIX w.) i kościół św. Rocha w Dąbrówce². Pozostałe erygowano dopiero w XX w. ${ }^{3}$. Do starszych niż Biegonice ośrodków religijnych na Sądecczyźnie należą parafie w Podegrodziu ${ }^{4}$ i św. Elżbiety w Starym Sączu oraz związana z kultem św. Andrzeja Świerada w Tropiu6 . Od XIII stulecia do lat siedemdziesiątych XX wieku, gdy w dwóch etapach samodzielną wieś Biegonice włączono w granice Nowego Sącza, istniała ona jako odrębna miejscowość lokowana na prawie niemieckim w drugiej połowie wieku XIII7.

Nie zachował się akt erekcyjny parafii, nie ma również żadnego dokumentu, który ex post określałby okoliczności i czas jej powstania. Już w XVIII wieku proboszcz Jan Sitowski zauważał, że nie istniał formalny dekret erekcji parafii ${ }^{8}$, przy czym trudno określić, czy

* Dr Marek Smoła: nauczyciel historii w IV LO w Tarnowie, wykładowca w tamtejszej PWSZ. Zainteresowania badawcze skupia na historii Kościoła na obszarze obecnej diecezji tarnowskiej w okresie staropolskim oraz na historii Tarnowa; e-mail: mareksmola69@gmail.com.

1 S. Salaterski, Kolegiata i kapituła św. Małgorzaty P.M. w Nowym Sączu (1448-1791), Nowy Sącz 1997, s. 15.

2 Ioannis Dlugosz senioris canonici Cracoviensis Liber beneficiorum dioecesis Cracoviensis. Opera omnia, vol. II, cura A. Przezdziecki, Cracoviae 1864, s. 237.

3 Zob. B. Kumor, Parafia i życie kościelne, w: Dzieje miasta Nowego Sącza, red. F. Kiryk, t. 3, Warszawa-Kraków 1996, s. 188.

4 Zob. A. Jureczko, W średniowieczu, w: Podegrodzie i gmina podegrodzka. Zarys dziejów, red. F. Kiryk, Kraków 2014, s. 91-93.

5 F. Kiryk, Dzieje miasta w okresie staropolskim, w: Historia Starego Sącza od czasów najdawniejszych do 1939 roku, red. H. Barycz, Nowy Sącz 2007, s. 53; tenże, Sądecka Pani, „,Rocznik Sądecki”, 1999, t. 27, s. 14; D. Zygmunt, Historia parafii p.w. św. Elżbiety w Starym Saczu od XIII w. do 1786 r., [mps], Kraków 2009, s. 35-37.

6 Zob. np. S. Wróblewski, Początki chrześcijaństwa w Sąecczyźnie w świetle dyskusji o chrystianizacji Małopolski w IX-X wieku, „Rocznik Sądecki”, 2017, t. 45, s. 33-47.

7 Zob. np. F. Sikora, Biegonice, w: Stownik Historyczno-Geograficzny Województwa Krakowskiego w średniowieczu, oprac. Z. Leszczyńska-Skrętowa, F. Sikora, cz. 1, z. 1: A-Borek, Wrocław-Warszawa-Kraków-Gdańsk 1980, s. 89-90; J. Rajman, Osadnictwo okolic Nowego Sacza i ksztaltowanie się strefy podmiejskiej średniowiecznego miasta (XIII-XV w.), w: Dzieje miasta Nowego Sącza, red. F. Kiryk, t. 1, Warszawa-Kraków 1992, s. 56.

8 Archiwum Kurii Metropolitarnej w Krakowie [dalej: AKMK], Tabele Załuskiego [dalej: TZ], nr 32. 
nie znano go wcześniej w ogóle, czy może uległ zniszczeniu w wyniku pożaru kościoła w I646 roku. Za tą drugą wersją przemawia znana z XIX wieku korespondencja między proboszczem biegonickim, ks. Józefem Zielińskim, a konsystorzem biskupim w Tarnowie, z której wynika, że właśnie w okresie jego urzędowania (I874-I88I) do Biegonic wysłano za pośrednictwem dziekana starosądeckiego kopię aktu erekcyjnego probostwa, a proboszcz kwitował jej otrzymanie ${ }^{9}$. Dokument ten nie zachował się jednak ani w zasobach archiwum parafialnego, ani w aktach konsystorskich Archiwum Diecezjalnego w Tarnowie. Ponad pół wieku temu datę powstania parafii na rok I269 określił ks. Bolesław Kumor, publikując materiały do Atlasu Historycznego Chrześcijaństwa w Polsce ${ }^{\mathrm{I0}}$. Oparł się na inwentarzu parafialnym z I669 roku, w którym zapisano, że ks. Kunegunda za zgodą Pawła z Przemankowa, biskupa krakowskiego, wystawiła dokument fundacyjny kościoła parafialnego w Biegonicach ${ }^{\text {II }}$. Niektórzy historycy (F. Sikora ${ }^{\mathrm{I2}}$, P. Stanko ${ }^{\mathrm{I3}}$ ) kwestionują tę datę, podkreślając, że odwołanie do niej znalazło się dopiero w źródle z drugiej połowy XVII wieku. Jednocześnie wskazują, że parafia sięga swą genezą XIII wieku, zauważając, że pierwsza niepodważalna informacja ma związek z potwierdzeniem oddania świętopietrza na rzecz Stolicy Apostolskiej, o którym wiadomo, że w I326 roku „Clemens, plebanus ecclesie de Beganicz" zapłacił 7 skojców i 5 denarów ${ }^{14}$.

Nie zauważono dotąd notatki, zamieszczonej w Księdze inwentarzy kościelnych, dokonanej ok. I659 roku przez ówczesnego proboszcza ks. Adama Bydłoniewicza, który właśnie toczył spór z klaryskami zmuszającymi chałupników plebańskich do posług na swoją rzecz. Brzmi ona następująco: „Domina Cunegundis Ducissa Poloniae Henrico Famulo suo et Filio eius donavit in perpetuum unum mansum agri in quo aedificavit Ecclesiam in Villa Bieganice Anno Dni 1269 ex consensu Reverendi Pauli Episcopi Cracoviensis. Ex archivo Sancti Monialium"'5. Na tę samą notatkę powoływał się nieco później jeden z kolejnych proboszczów, Mikołaj Jan Kanty Woszczyński, również procesujący się z klaryskami ${ }^{16}$.

Określenie roku erekcji parafii jest ważne dla podejmowanych tu rozważań, bo każe poszukiwać jej proboszczów w źródłach sięgających już drugiej połowy XIII wieku. Przyjęto również, że cezurą zamykającą zakres czasowy będzie rok I795, oznaczający koniec okresu staropolskiego, zbieżny w Biegonicach ze śmiercią proboszcza Franciszka Pasiewicza.

\footnotetext{
9 „Zachowując w tutejszym archiwum oryginał aktu erekcyjnego tamtejszego probostwa z r. 1541, przesyła biskupi konsystorz kopią tegoż aktu aprobowaną dla dalszego przechowania w archiwum parafialnym", Archiwum Diecezjalne w Tarnowie [dalej: ADT], Akta lokalne Nowy Sącz-Biegonice [dalej: ALNSB], Pismo konsystorza biskupiego w Tarnowie z 6 stycznia $1879 \mathrm{r}$.

10 B. Kumor, Archidiakonat sadecki. Opracowanie materiałów źródtowych do Atlasu Historycznego Kościoła w Polsce, „Archiwa, Biblioteki i Muzea Kościelne”, 1964, t. 8, s. 295.

11 ADT, ALNSB, Inventarium ecclesiae parochialis s. Laurentii Bieganicensis anno Domini 1669 [regest].

12 F. Sikora, Biegonice..., dz. cyt., s. 90.

13 P. Stanko, Najstarsze inwentarze kościoła parafialnego w Nowym Sączu-Biegonicach z XVI-XVII wieku, „Almanach Sądecki”, 19/2010, $\mathrm{nr}$ 1/2 (70/71), s. 3-23.

14 Monumenta Poloniae Vaticana, t. 1: Acta Camerae Apostolicae, vol. 1: 1207-1344, red. J. Ptaśnik, Cracoviae 1913 [dalej: MPV], s. 145.

15 ADT, Księga inwentarzy kościelnych [dalej: KIK], tekst poza inwentarzem, pod rokiem 1659.

16 AKMK, AOff., t. 162 , s. 286, s. 287-288, s. 399-400, s. 505-506, s. 507; tamże, t. 163, s. 168. Zob. także: Archiwum Parafialne w Biegonicach [dalej: APB], Dowody y obrona dla Informatyey Przewielebney Mości Panny Xienżney y wszystkiego Światobliwego Zgromadzenia w tym iako dway chatupnicy Plebanszczy do żadnych podatków Bieganskiey Gromady niepowinni się przyktadać, [dokument sprzed 1670 roku w odpisie z 1686 r.], [rps].
} 
Zasób źródłowy to przede wszystkim materiały wytworzone lokalnie, zachowane w archiwum parafialnym, wśród nich inwentarze i notatki gospodarcze. I choć właściwie pomijają nazwiska proboszczów, pozwalają - poprzez porównanie z innymi źródłami - przypisać konkretnym postaciom podejmowane działania. Dlatego warto wspomnieć inwentarze z lat I739, I775 i I $785^{17} \mathrm{czy}$ inne pisma dotyczące uposażenia plebana i organisty albo też działania proboszczów w zakresie ubogacania kościoła parafialnego ${ }^{\mathrm{I} 8}$.

Bardzo ważnym źródłem okazał się Elenchus obejmujący informacje o pracujących w parafii duchownych. Znany jest w dwóch wersjach, choć obie powstały retrospektywnie w XIX wieku, co można rozpoznać, porównując charakter pisma prowadzących je osób. Umieszczone są w jednym rękopisie. Wersja pierwsza kończy się informacją o śmierci proboszcza Antoniego Koralewicza (I7 grudnia I838 roku), powstała więc po tym roku ${ }^{\mathrm{I}}$. Druga obejmuje więcej informacji o poszczególnych duchownych, podaje często konkretne daty instalacji w parafii, posiadanie przez proboszczów innych beneficjów lub pełnienie różnych funkcji kościelnych, choćby to, że byli spowiednikami klarysek ${ }^{20}$. Równie cenna jest podjęta pod koniec XIX wieku przez zasłużonego dla parafii ks. Andrzeja Niemca próba zebrania materiałów dotyczących historii kierowanej przez niego wspólnoty. Przygotowując obszerną monografię poświęconą Biegonicom, zebrał znaczną ilość materiału, którego nie zdążył opracować z powodu swojej śmierci, a które to notatki przepadły. Pozostał jedynie kilkustronicowy szkic, który obejmuje najważniejsze wydarzenia z dziejów parafiii ${ }^{21}$.

Cenne informacje zawierają najstarsze księgi parafialne przechowywane od 2010 roku w Archiwum Diecezjalnym w Tarnowie. Są wśród nich zarówno wspomniane już wyżej inwentarze z lat I596-I700 spięte w Księdze inwentarzy kościelnych, jak i księgi ochrzczonych $^{22}$, zaślubionych ${ }^{23}$ i zmarłych ${ }^{24}$. Co ważniejsze, wplecione są w nie prowadzone od I624 roku zapiski kolejnych proboszczów o wydatkach ponoszonych w zakresie remontów budynków gospodarskich probostwa, plebanii, kościoła czy na zakup różnych paramentów kościelnych.

Dokonano kwerendy w zasobie Archiwum Kurii Metropolitalnej w Krakowie, przeszukując akta biskupie, administratorów czy oficjałów, jak również inne materiały. Wykorzystano zachowane w dzisiejszym kształcie archiwum klasztoru starosądeckich klarysek, które posiadały prawo patronatu wobec biegonickiej parafii. To właśnie konwent prezentował biskupowi kandydatów do urzędu proboszcza, miały więc klaryski nie tylko wiedzę na temat kandydatów, ale także jakieś motywy, którymi swoje decyzje uzasadniały.

\footnotetext{
17 APB, Inventarium Ecclesiae Biganicensis [1739], [dalej: Inw. 1739]; tamże, Inventarium Parochialis Biegunicensis Tituli S. Laurentii Dioecesis Cracoviensis Decanatus Sandecensis [...] in circulo Velicensis Districtu Sandecensi [brak daty, zapewne ok. 1775], [dalej: Inw. 1775]; tamże, Inventarium vasorum, praetiosorum et apparamentorum Ecclesiae Parochialis in pago Biegonice, 17 julii 1785 [dalej: Inw. 1785].

18 APB, Obmyślenie dla organisty sustencyi, [1752 r.], [rps]; APB, Relacja ks. Sitowskiego [bez daty, II poł. XVIII w.], [rps]; APB, Dowody y obrona ..., dz. cyt.

19 APB, Elenchus I.

20 APB, Elenchus II.

21 APB, Pro memoria notatur [rps].

22 ADT, KCh 1653; ADT, KCh 1681; ADT, KCh 1738.

23 ADT, KŚ 1653; ADT, KŚ 1681; ADT, KŚ 1738.

24 ADT, KZ 1738.
} 
Szczególnie popularna ostatnio prozopograficzna metoda badawcza pozwala na podejmowanie działań służących analizowaniu choćby społeczności duchownych posługujących w określonym czasie w jednej parafii. Wnioski mogą ułatwić zrozumienie procesów zachodzących w zarządzaniu parafią, zarysować relacje między proboszczami jako panami feudalnymi a ich poddanymi, odszukać prawidłowości w postępowaniu klasztoru jako prezentującego kandydatów, biskupów krakowskich jako powołujących na urząd. Można wreszcie analizować pochodzenie społeczne czy wykształcenie kolejnych plebanów, którzy - także poprzez swoje charakterologiczne czy intelektualne przymioty - mogli oddziaływać na powierzoną sobie wspólnotę wiernych. Wreszcie odnalezione w ten sposób związki z administracją kościelną pozwalają na określenie stopnia kumulacji beneficjów czy roli w zarządzaniu dekanatem, archidiakonatem sądeckim czy diecezją krakowską.

Warto zauważyć, że do tej pory lokalny Kościół doczekał się kilku opracowań tego typu. Mają swoje katalogi prałatów i kanoników kapituła kolegiacka w Tarnowie ${ }^{25}$, podobne kapituły w Nowym Sączu ${ }^{26}$ i Wojniczu ${ }^{27}$ czy probostwo św. Elżbiety w Starym Sączu ${ }^{28}$ i szpitalne probostwo św. Krzyża w tymże mieście ${ }^{29}$. W ostatnich latach pojawiło się sporo opracowań w tym zakresie, także w szerszym geograficznie wymiarze, jak choćby prozopograficzne studia o duchowieństwie diecezjalnym ${ }^{30}$, duchowieństwie kapituł katedralnych ${ }^{31}$, duchowieństwie miejskim ${ }^{32}$ czy zgromadzeniach zakonnych ${ }^{33}$.

Przeprowadzona w różnych archiwach kwerenda i analiza materiałów drukowanych pozwoliła odszukać łącznie 29 duchownych, którzy od momentu utworzenia parafii do I795 roku pracowali w biegonickiej parafii. O niektórych informacje są bardzo szczątkowe, wręcz jednostkowe, biogramy innych można uszczegółowić o wiele elementów związanych z pochodzeniem, wykształceniem czy dokonaniami w parafii. W sąsiedniej parafii św. Elżbiety w Starym Sączu udało się zestawić dla mniej więcej podobnego okresu 26 proboszczów ${ }^{34}$. W przypadku Biegonic właściwie tylko do pierwszej połowy XVI wieku nie da się określić skrajnych lat urzędowania poszczególnych plebanów. Od Stanisława Wąsowicza ta ciągłość w Biegonicach jest w pełni potwierdzalna. W przypadku wcześniejszych proboszczów czasami da się określić jedną ze skrajnych dat (rozpoczęcia albo zakończenia) urzędowania lub inną, związaną z jakąś formą aktywności w okresie posługi proboszczowskiej. W takim wypadku oznaczono je w tabeli kursywą.

\footnotetext{
25 F. Herzig, Katedra niegdyś kolegiata w Tarnowie wraz z krótka wzmianka o innych kościołach w Tarnowie, Tarnów 1900.

26 S. Salaterski, Kolegiata..., dz. cyt.

27 J. Szymański, Kapituła kolegiacka w Wojniczu 1465-1786, Lublin 1962.

28 W. Bazielich, Parafialni proboszczowie starosadeccy, „Nasza Przeszłość” [dalej: NP], 1959, t. 9, s. 91-155.

29 W. Bazielich, Materiały do historii szpitala, kościoła i prepozytury św. Krzyża w Starym Saczu, NP, 1961, t. 14, s. 203-247.

30 Zob. J. Szczepaniak, Duchowieństwo diecezji krakowskiej w XVIII wieku. Studium prozopograficzne, Kraków 2010.

31 Zob. R. Krajniak, Duchowieństwo kapituly katedralnej w Chetmży do 1466 roku, Torun 2013.

32 Zob. S. Jujeczka, Duchowni średniowiecznej Legnicy. Studium prozopograficzne, Legnica 2006; M. Sumowski, Duchowni w średniowiecznym Toruniu. Studium prozopograficzne, Toruń 2012.

33 Zob. P. Gąsiorowska, Konwent Klarysek krakowskich do końca XVIII wieku. Studium prozopograficzne, Kraków 2015.

34 Zob. D. Zygmunt, dz. cyt., s. 97.
} 
Tab. I. Proboszczowie parafii św. Wawrzyńca w okresie staropolskim

\begin{tabular}{|c|c|c|}
\hline Lp. & Imię i nazwisko & Okres \\
\hline I & Arnold z Wrocławia & I3I3 \\
\hline 2 & Klemens & $1326-1328$ \\
\hline 3 & dr Jan Białka & $I 46 I$ \\
\hline 4 & Maciej z Czorsztyna & do 1519 \\
\hline 5 & Albert ze Starego Sącza & od I6.06.1519 \\
\hline 6 & Maciej & $I 52 I$ \\
\hline 7 & Stanisław z Lipnicy & 1529 \\
\hline 8 & Maciej & do II.03.I533 \\
\hline 9 & Marcin z Proszowic & od 2.04.1533 \\
\hline IO & Adrian z Kościana Habdański & $I 54 I-5[\mathrm{brak}] \mathrm{I} 574$ \\
\hline II & Jan Milanowski & 30.04.1574 - przed 20.06.1576 \\
\hline $\mathrm{I} 2$ & Stanisław Wąsowicz & 20.06.I576 - przed 24.04.I59I \\
\hline I3 & Andrzej Dąbrowski & I59I - przed 29.04.I592 \\
\hline I4 & Andrzej Wargowski & 29.04.1592 - I4.03.I608 \\
\hline 15 & dr Stanisław Sistowski & po $19.07 .1608-$ I6IO \\
\hline I6 & Mikołaj Wąsowicz & I8.06.I6IO - I6I5 \\
\hline 17 & Stanisław Wciankowicz & I615-30.04.1624 \\
\hline I8 & Sebastian Zagrodzki & przed I9.05.I624-przed 4.07.I638 \\
\hline I9 & dr Szymon Jaroszowski & przed $4.07 .1638-\mathrm{I} 653$ \\
\hline 20 & dr Adam Bydłoniewicz & przed I3.07.1653-23.05.1670 \\
\hline $2 \mathrm{I}$ & Sebastian Machowicz & przed 22.06.I670 - przed I7.06.I68I \\
\hline 22 & Mikołaj Jan Kanty Woszczyński & przed I7.06.I68I - I7II \\
\hline 23 & dr Tomasz Józef Majowski & 08.I7II - przed 27.04.I733 \\
\hline 24 & dr Kazimierz Pałaszowski & $27.04 .1733-\mathrm{I} 2 . \mathrm{I} 737$ \\
\hline 25 & Karol Paweł Dzierzgowski & I8.OI.I738 - I2.I744 \\
\hline 26 & Jan Sitowski & 3.0I.I745-6.06.I775 \\
\hline 27 & Wojciech Józef Mroziński & $28.08 .176 \mathrm{I}-20.04 .1769$ \\
\hline 28 & dr Franciszek Pasiewicz & 26.06.I775 - I.OI.I795 \\
\hline 29 & Ignacy Bartsch & 20.09.1776 - [brak] \\
\hline
\end{tabular}

Spośród proboszczów, których daty urzędowania dało się określić, najdłużej urząd ten pełnił ks. Adrian z Kościana (co najmniej 33 lata), natomiast 30 lat urzędował ks. Woszczyński. Posługa ks. Sitowskiego trwała również 30 lat, ale przez dziewięć lat toczył on spór z ks. Mrozińskim, na rzecz którego musiał w pewnym momencie opuścić parafię. Ks. Majowski pełnił urząd przez 22 lata, zaś lat 20 trwał na stanowisku ks. Pasiewicz. 
Dość jednoznaczna wydaje się możliwość określenia diecezji pochodzenia kolejnych proboszczów. Do połowy XVI wieku dwóch mogło mieć związki z innymi diecezjami - ks. Arnold z wrocławską i ks. Adrian z poznańską. W przypadku czterech z tego okresu miejsce urodzenia wiąże raczej z diecezją krakowską, zaś diecezji pochodzenia czterech innych określić się nie da. Z kolei od I574 roku tylko w przypadku trzech (Dąbrowski, Milanowski, Sistowski) można mieć wątpliwości, czy pochodzili z diecezji krakowskiej. U pozostałych takie związki można bezwzględnie lub potencjalnie (Bartsch) potwierdzić.

W wielu wypadkach znane są również miejsca urodzenia biegonickich proboszczów. Nie powinno dziwić, że aż siedmiu urodziło się w Starym Sączu. Dwóch mogło pochodzić z Krakowa (Bartsch i Pałaszowski), ponadto po jednym z Biecza, Czorsztyna, Kościana, Lipnicy (nie wiadomo której), Łącka, Muszyny, Pieskowej Skały, Proszowic, Szczekocin i Wrocławia. W przypadku dziesięciu proboszczów nie udało się ustalić miejscowości pochodzenia.

Bardzo trudno jest również analizować ich pochodzenie społeczne. Szlachectwo wśród biegonickich proboszczów udało się potwierdzić w przypadku trzech - ks. Maciej (usunięty w I533 roku), ks. Jaroszowski i ks. Adrian (z rozpoznanym herbem Abdank), w przypadku dwóch - Dąbrowski i Sitowski - pochodzenie szlacheckie jest domniemywane. Bezwzględnie za to można potwierdzić mieszczańskie pochodzenie I7 duchownych. W przypadku pozostałych zachowane dane nie pozwalają na podjęcie takich analiz. W XVI wieku pewna część szlachty w Sądeckiem bliska była ideałom reformacji, stąd też pewnie zmniejszenie się liczby chętnych do karier duchownych. Pamiętać też trzeba, że święcenia kapłańskie stanowiły swoistą nobilitację, więc też w przypadku synów mieszczańskich, zwłaszcza ze słabszych ekonomicznie ośrodków, stanowiły one szansę na awans społeczny.

Biegonicka parafia była stosunkowo intratna finansowo. Dość powiedzieć, że w I748 roku dochody proboszcza szacowano na 500 florenów, gdy w sąsiednich Barcicach na 350, a w Żeleźnikowej na 220 florenów ${ }^{35}$. Dla porównania warto pokazać, że dochody prałatur i kanonii w pobliskich kapitułach rzadko przewyższały dochody biegonickiego plebana. W Nowym Sączu na 12 godności cztery miały większe dochody niż prebendarz św. Wawrzyńca ${ }^{36}$. W Tarnowie na I6 godności trzy przewyższały dochodami biegonickiego plebana, zaś w przypadku kapituły wojnickiej, gdzie istniało I3 godności, większe dochody miało zaledwie pięć37. Ponieważ sytuuje to probostwo biegonickie wysoko w rankingu dochodowości beneficjum, można spodziewać się, że - szczególnie w XVII i XVIII wieku - trudniej było je zająć choćby chłopskim synom, co jeszcze praktykowano często w wieku XVI ${ }^{38}$.

Kolejnym elementem podjętej analizy porównawczej w przypadku biegonickich proboszczów jest posiadane wykształcenie. W przypadku I4 duchownych da się potwierdzić: posiadanie biblioteki bez jednoczesnego potwierdzenia stopnia naukowego (Zagrodzki), podjęcie studiów (M. Wąsowicz), posiadanie wiedzy prawniczej bez określenia stopnia (Adrian, Wargocki) lub uzyskanie różnych tytułów naukowych (Białka, Bydłoniewicz, Jaroszowski, Machowicz, Majowski, Marcin z Proszowic, Pałaszowski, Pasiewicz, Sistowski,

\footnotetext{
35 AKMK, TZ, nr 31, 32, 54.

36 S. Salaterski, Kolegiata..., dz. cyt., s. 105.

37 J. Szymański, Kapituła..., dz. cyt., s. 75.

38 Można się tu odwołać do, obejmującej nieco inny obszar administracji kościelnej, pracy: J. Kracik, Vix venerabilies. Z dziejów społecznych niższego kleru parafialnego $w$ archidiakonacie krakowskim $w$ XVII-XVIII wieku, Kraków 1982.
} 
S. Wąsowicz). Największą pozycję naukową osiągnął ks. Pałaszowski jako trzykrotny dziekan Wydziału Filozoficznego (przed objęciem probostwa) i dwunastokrotny rektor Akademii Krakowskiej (po opuszczeniu Biegonic). Czterech biegonickich proboszczów uzyskało więcej niż jeden stopień naukowy - Bydłoniewicz, Machowicz, Majowski i Pałaszowski. Siedmiu plebanów posiadało doktoraty (w tym Bydłoniewicz dwa), przy czym Pałaszowski, Pasiewicz i Sistowski z teologii, Bydłoniewicz i Majowski z filozofii, Jaroszowski z obojga praw, Bydłoniewicz z zakresu sztuk wyzwolonych, nieokreślony doktorat posiadał Białka. Pałaszowski posiadał ponadto magisterium sztuk wyzwolonych, bakalaureat artium posiadali Machowicz, Majowski, Marcin z Proszowic i S. Wąsowicz, zaś bakałarzami filozofii byli Bydłoniewicz, Machowicz i Majowski. O poziomie wykształcenia Pałaszowskiego i jego miejscu w strukturach uniwersytetu może świadczyć fakt, że pełnił też funkcję kaznodziei zamkowego w Krakowie. Zapewne większość z nich studiowała i zdobywała stopnie naukowe w Krakowie, wiadomo też, że Pasiewicz uczył się w gimnazjum pijarów w Podolińcu i gimnazjum jezuickim w Jarosławiu. Można zauważyć, że uzyskanie stopni naukowych wyraźnie pozwalało podnieść pozycję duchownych w życiu społecznym i w strukturach Kościoła. Tym bardziej trafne wydaje się to spostrzeżenie, jeśli zauważy się, iż większość posiadających stopnie naukowe to mieszczanie.

Jednym z wymiarów uzyskanego wykształcenia i szerokich zainteresowań niektórych proboszczów jest fakt gromadzenia przez nich książek. Trzej - Bydłoniewicz, Machowicz i Zagrodzki - zebrali pokaźne księgozbiory. Ks. Bydłoniewicz swój księgozbiór przekazał w testamencie bibliotece kustoszowskiej przy kolegiacie sądeckiej, choć kilka tytułów pozostało w parafii. W tej liczbie wymienia się dzieła Boecjusza, Terencjusza oraz Ewangelie i Listy w tłumaczeniu ks. Wujka ${ }^{39}$. Machowicz swoją bibliotekę zapisał na rzecz klasztoru, księgi łacińskie przeznaczając dla spowiedników i kapelanów klasztornych, a polskie dla zakonnic. Były to dzieła treści religijnej i teologicznej, a między łacińskimi znajdował się także Index librorum prohibitorum ${ }^{40}$. Równie znaczący musiał być księgozbiór Zagrodzkiego, który ofiarował swe książki klasztorowi reformatów w Bieczu. Z ich liczby w 1977 roku istniało jeszcze 2I pozycji ${ }^{4}$.

Nie ma odwołań do innych kwalifikacji duchownych obejmujących biegonicką parafię, choć oczywiście podstawowymi są święcenia kapłańskie. W jednym wypadku - S. Wąsowicza - wiadomo, że w momencie prezentowania na urząd proboszcza miał zaledwie niższe święcenia ${ }^{42}$. Daty uzyskania prezbiteratu znane są w przypadku jedynie kilku: ks. Dzierzgowski przyjął je 24 marca I70843, ks. Machowicz 24 lutego I64644, ks. Mroziński 3I maja I74445,

\footnotetext{
39 BPAN, rps 1643, k. 86-87; ADT, KIK, pod rokiem 1670.

40 W. Bazielich, Materialy do historii..., dz. cyt., s. 230; tegoż, Resztki „Biblioteki parafialnej” w Starym Saczu, „Roczniki Biblioteczne”, t. 6, 1962, s. 147-170.

${ }^{41}$ APB, Pismo O. Modesta Jana Pasiecznika do proboszcza w Biegonicach z 12 grudnia 1977 r.

42 AKMK, AOff., t. 107, s. 493.

43 AKMK, AVCap., t. 60, s. 138; tamże, LOrd., t. 6, s. 307; tamże, t. 7, s. 53, 55, 59.

${ }^{44}$ AKMK, AEp., t. 54, k. 182, k. 236; zob. także, J. Szczepaniak, Katalog duchowieństwa diecezjalnego zestawiony na podstawie krakowskich ksiąg święceń (1646-1789), t. 2: J-M, Kraków 2008, s. 650.

${ }_{45}$ AKMK, AV, t. 49, s. 152; tamże, LOrd., t. 9, s. 429, 430, 432; AKMK, Decriptio ecclesiarum parochialium et beneficiorum consistentium cum circumctantiis in Tabela Normali ab Excelso Gubernio sub die 2da septembris anni elapsi porrecta specificatis facta, Anno Domini 1776, s. 20, 23.
} 
ks. Pałaszowski 6 marca $1729^{46}$, ks. Pasiewicz w I $74 \mathrm{I}^{47}$, ks. Sitowski 20 września $1727^{48}$, zaś ks. Woszczyński II czerwca I66I roku ${ }^{49}$. Jedynie w przypadku ks. Woszczyńskiego wiadomo, że do kapłaństwa przygotowywał się w seminarium zamkowym w Krakowie, w jednym też wypadku (ks. Sitowskiego) znana jest dziedzina, w której specjalizował się podczas studiów (teologia moralna), zaś w przypadku dwóch proboszczów znani są biskupi udzielający im święceń - ks. Sitowski przyjmował je od sufragana krakowskiego Michała Kunickiego, zaś ks. Woszczyński od pełniącego podobną funkcję Mikołaja Oborskiego.

W kilku przypadkach można określić wiek proboszczów obejmujących biegonicką parafię. Znane są daty urodzenia sześciu z nich, u niektórych można ją ostrożnie szacować, ale w przypadku większości nie ma takich informacji. Dla poniższej analizy wykorzystano tylko potwierdzone informacje o dacie urodzenia. Średnia wieku duchownych obejmujących parafię wyniosła ok. 44 lata. Najmłodszym, który objął biegonicką parafię w wieku 37 lat, był ks. Mroziński. Z kolei ks. Wciankowicz został proboszczem w wieku lat 39. Dwóch duchownych - Bydłoniewicz i Pałaszowski - zostało proboszczami w wieku lat 4I. Ks. Sitowski osiągnął przed nominacją proboszczowską 44 lata, najstarszym zaś, był ks. Pasiewicz, który, obejmując parafię, miał 60 lat.

Warto przyjrzeć się również osobom prezentującym na urząd proboszcza. Nominalnie powinien być to klasztor starosądeckich klarysek, który - zapewne od czasu fundacji św. Kingi - stał się patronem parafii i prawo to realizował do wieku XVIII. Jednak w praktyce zdarzały się sytuacje, że kandydatów obsadzano na stanowisku na mocy prezenty innych instytucji. Pierwszym, o którym wiadomo na pewno, że prezentowały go klaryski, był ks. Jan Milanowski, powołany na urząd proboszcza 30 kwietnia 1574 roku. Jego kandydaturę biskupowi krakowskiemu przedstawiła ksieni Dorota Bylicka ${ }^{50}$. Ta sama, wraz z kilkoma matkami, prezentowała kolejnego proboszcza, ks. S. Wąsowicza ${ }^{51}$. Ks. M. Wąsowicza prezentowały Anny Gostwicka, przełożona klasztoru, Zofia Boczkowska, wikaria, oraz Katarzyna Płuszowska ${ }^{52}$, natomiast ks. Machowicza, 27 maja I670 roku, prezentowała ksieni Zofia Stanówna ${ }^{53}$.

Generalnie respektowano prawo prezenty patrona parafii, choć w licznych parafiach miały miejsca konflikty dotyczące obsady probostw. Zdarzało się, że nominacji dokonywano na podstawie prowizji papieskiej lub prawa rezerwacji. W I5I9 roku papież Leon X postanowił, że Stolica Apostolska będzie miała prawo obsady beneficjów w miesiącach nieparzystych, zaś Grzegorz XIII w 1584 roku zarezerwował kurii rzymskiej prawo obsady beneficjów po śmierci prałatów kurialnych ${ }^{54}$.

Pierwszym znanym w Biegonicach duchownym, który mógł uzyskać prezentę proboszczowską z innego źródła, był ks. Dąbrowski. Po śmierci poprzednika zdobył poparcie

\footnotetext{
46 AKMK, AAdm., t. 24, s. 825; AKMK, AOff., t. 171, s. 1031.

47 W. Bazielich, Materiaty do historii..., dz. cyt., s. 232.

48 AKMK, LOrd., t. 8, s. 49; AKMK, LOrd., t. 9, s. 10, 16; AKMK, TZ, t. 12, tab. 32.

49 AKMK, LOrd., t. 4, k. 196, 205 v, 207v, 211; zob. także: J. Szczepaniak, Odtworzone katalogi seminariów diecezji krakowskiej (XVII-XVIII w.), Kraków 2005, s. 63.

50 AKMK, AOff., t. 106, s. 1209.

51 AKMK, AOff., t. 107, s. 493.

52 AKMK, AOff., t. 116, s. 159-163.

53 ADT, KIK, pod rokiem 1670.

54 B. Kumor, Dzieje diecezji krakowskiej, t. 4, Kraków 2002, s. 624-626.
} 
Annibala z Capui, arcybiskupa Neapolu, protonotariusza apostolskiego, nuncjusza apostolskiego w Polsce w latach I586-I59I55. Nie znane są okoliczności tych starań, choć wiadomo, że ks. Dąbrowski uzyskał również poparcie oficjała generalnego krakowskiego i wikariusza in spiritualibus, Pawła Dembskiego, administratora diecezji krakowskiej po śmierci bpa Piotra Myszkowskiego. Probostwo objął na krótko, ale musiał je opuścić przed 29 kwietnia 1592 roku, gdy mianowano jego następcę ${ }^{5}$. Inny tego rodzaju przypadek miał miejsce w I7II roku, gdy ks. Woszczyński dobrowolnie zrezygnował z urzędu proboszcza, a „SS. sedes apostolica Thomam Maiowski parochum facit" ${ }^{\prime}$. Wiadomo również, że po śmierci tegoż, w bliżej nieznanych okolicznościach, popierano nieokreślonego kandydata, być może ks. Pałaszowskiego. Dokument powołujący go na proboszcza został wystawiony z datą 27 kwietnia 1733 roku $^{58}$.

Najpoważniejszy konflikt o obsadę urzędu biegonickiego proboszcza miał miejsce w latach I76I-I769. Nie wiadomo, czy ks. Sitowski był prezentowany przez klaryski, natomiast bez wątpienia cieszył sie jakimś poparciem ze strony ks. Adama Komorowskiego, w latach I729-I736 archidiakona sądeckiego, później prepozyta kapituły katedralnej w Krakowie, komisarza konwentu klarysek, którego wpływy chciał wykorzystać w sporach toczonych z poddanymi o zagarniętą z dóbr plebańskich ziemięę9. Powołany na prymasa Polski abp Komorowski zmarł w 1759 roku, a wraz z jego śmiercią ks. Sitowski stracił protektora. Z jakiegoś powodu został wkrótce, przed 4 sierpnia I76I roku, pozbawiony godności proboszcza na mocy dekretu sędziowskiego przez bpa Franciszka Potkańskiego ${ }^{60}$. Właśnie tego dnia w obecności tegoż biskupa, wikariusza i oficjała generalnego, oraz egzaminatorów prosynodalnych: Stanisława Mamczyńskiego, kanonika krakowskiego; Kazimierza Jarmundowicza, kanonika krakowskiego i kustosza kolegiaty Wszystkich Świętych w Krakowie; Kazimierza Stęplowskiego, dra teologii i dziekana kapituły św. Floriana w Krakowie, odbył się swego rodzaju egzamin, na który stawił się tylko Antoni Jarzęcki, dr filozofii, prebendariusz w Szczepanowie ${ }^{6}$. Powtórzono go 28 sierpnia w obecności tych samych osób. Tym razem stawiło się trzech kandydatów: Szymon Banaszkowski, dr filozofii, prof. UJ; kleryk niższych święceń, Antoni Jarzęcki, wspomniany wcześniej prebendariusz w Szczepanowie, oraz Wojciech Mroziński, kanonik kolegiaty Wszystkich Świętych w Krakowie, proboszcz w Siedlcach. Decyzją biskupa wybrano tego ostatniego ${ }^{62}$. We wrześniu I76I roku został zainstalowany w biegonickim kościele w obecności trzech dostojników: Antoniego Eugeniusza, prałata domowego Ojca św. Klemensa XIII; Franciszka Potkańskiego, biskupa patareńskiego, sufragana, kanonika, wikariusza i oficjała generalnego krakowskiego; oraz

\footnotetext{
55 A. Przeździecki we wstępie do wydanych listów tego hierarchy zauważa, że przebywał on w Polsce w latach 1586-1590. Natomiast lata 1586-1591 podaje: R. Skowron, Nuncjusz i ambasador. Korespondencja Annibala z Capui z Guillenem de San Clementem (1586-1591), w: Od Kijowa do Rzymu. Z dziejów stosunków Rzeczypospolitej ze Stolica Apostolska i Ukraina, red. M.R. Drozdowski, W. Walczak, K. Wiszowata-Walczak, Białystok 2012, s. 453.

56 AKMK, AOff., t. 111, s. 127-128.

57 APB, Elenchus II, s. 4.

58 AKMK, AOff, 171, s. 699-700.

59 APB, Relacja ks. Sitowskiego [przed 1775 r.], [rps].

60 ADT, KCh 1738, [rps], [brak pag.] - tam zapis: ab Officio... G[e]n[er]ali Crac.

61 AKMK, AOff., t. 193, s. 393-394.

62 Tamże, s. 398-399.
} 
Grzegorza Jana Sikorskiego, kanonika i sędziego surogata sądeckiego ${ }^{63}$. Ks. Sitowski odwołał się do nuncjatury i trybunału papieskiego. W marcu 1762 roku wpisał w księdze chrztów, że na mocy dekretu Trybunału Nuncjatury Apostolskiej w Polsce jest legalnym proboszczem i posiadaczem beneficjum w Biegonicach ${ }^{64}$, zaś w kwietniu określił się w księdze ślubów jako „legitimus plebanus Biegonicen.[sis]”. Z kolei Mroziński zapisał, że jest „jak najbardziej legalnym proboszczem na podstawie breve papieża Klemensa XIII" i że legalnie odzyskał beneficjum 22 czerwca 1762 roku $^{65}$. Spór musiał więc ciągnąc się dalej, a zakończył się dopiero 20 kwietnia 1769 roku, gdy ks. Sitowski ostatecznie wrócił do parafii za zgodą Stolicy Apostolskiej ${ }^{66}$.

Niejasna sytuacja miała również miejsce w 1776 roku, gdy proboszczem w parafii był ks. Pasiewicz, a jednocześnie stolica biskupia w Krakowie powołała na ten urząd ks. Bartscha ${ }^{67}$. W źródłach brak jest wyjaśnienia tego stanu prawnego, zresztą wkrótce po tej dacie jako proboszcz biegonicki konsekwentnie pojawia się ks. Pasiewicz.

Biegoniccy proboszczowie pełnili wiele ważnych funkcji w administracji kościelnej. Najwyższym lokalnym urzędem był archidiakonat sądecki, a jeden z biegonickich plebanów, Mikołaj Wąsowicz, objął ten urząd i choć wkrótce ustąpił z probostwa, przez co najmniej kilka miesięcy łączył obie funkcje. Co ważne, przeprowadził również wizytację archidiakonatu - w I6I8 roku - w tym parafii w Biegonicach ${ }^{68}$. Urząd dziekana sądeckiego piastowało aż czterech biegonickich proboszczów, w kolejności chronologicznej: M. Wąsowicz, Bydłoniewicz, Majowski, Dzierzgowski. W zarządzie diecezją krakowską pomagali również oficjałowie, sprawujący w administracji kościelnej funkcje sądownicze. I w tę rolę wcieliło się czterech proboszczów z Biegonic - (chronologicznie) Wargowski, M. Wąsowicz, Bydłoniewicz, Majowski. Zadania tzw. sędziego zastępczego (iudex surogat) wypełniał ks. Bydłoniewicz, natomiast ks. Sitowski był notariuszem konsystorza w Nowym Sączu.

Zgodnie z ówczesną praktyką, niektórzy z proboszczów, posiadając biegonicką parafię, obejmowali inne prebendy lub, mając takowe, byli instalowani na urząd proboszcza w Biegonicach. Aż sześciu spośród rządców parafii św. Wawrzyńca posiadało prepozyturę św. Krzyża w Starym Sączu związaną z lokalnym szpitalem. Byli to: ks. Adrian, ks. S. Wąsowicz, ks. Jaroszowski, ks. Bydłoniewicz, ks. Machowicz i ks. Pasiewicz. Trzej - ks. M. Wąsowicz, ks. Jaroszowski, ks. Majowski - pełnili również funkcję proboszczów parafii św. Elżbiety w Starym Sączu. Ks. Dzierzgowski, gdy obejmował parafię w Biegonicach, był proboszczem w Muszynie ${ }^{69}$, ks. Mroziński proboszczem w Siedlcach, ks. Pasiewicz proboszczem w Barcicach, zaś ks. Wargowski prepozytem szpitala i kościoła św. Walentego w Nowym Sączu. Niektórzy posiadali inne probostwa przed lub po urzędowaniu w Biegonicach. W grupie tej trzeba wymienić ks. Bydłoniewicza (probostwo w Piwnicznej piastował wcześniej), ks. Majowskiego (który chyba nie łączył probostwa w Biegonicach z wcześniej objętym probostwem w Nawojowej), ks. Mrozińskiego (parafię w Łącku objął po usunięciu z Biegonic),

${ }^{63}$ ADT, KZ 1738, zapis z września 1761.

${ }_{64}$ ADT, KCh 1738.

65 ADT, KŚ 1738.

${ }^{66}$ ADT, KCh 1738.

67 AKMK AEp. 100, s. 796.

${ }_{68}$ Zob. AKMK, AVCap., t. 39, s. 1.

${ }^{69}$ APB, Elenchus II, s. 4, podaje błędnie, że był proboszczem w Tyliczu. 
ks. Pałaszowskiego, który po rezygnacji z probostwa w Biegonicach objął podobne funkcje w parafii św. Szczepana w Krakowie i w Czernichowie, czy ks. Wciankowicza, który wcześniej był proboszczem w Piwnicznej.

Liczni biegoniccy proboszczowie kumulowali z prebendą parafialną beneficja wynikające z zasiadania w kapitułach. Najdostojniejszą pozycję w tym zakresie dawało miejsce w kapitule katedralnej w Krakowie ${ }^{70}$. Źródła parafialne wspominają, że nominację na kanonię w kapitule wawelskiej otrzymali ks. Wciankowicz („nominatus Canonicus Cracoviensis, qua ex dignitate resignavit”) i ks. Dzierzgowski (,tandem factus Canonicus Cracoviae[nsis]

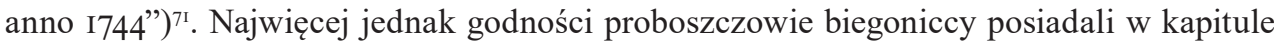
kolegiackiej w Nowym Sączu ${ }^{72}$. Najważniejszą prałaturę - prepozyturę - objęli ks. M. Wąsowicz (I604-I6I4) i ks. Jaroszowski (I64I-I653). Drugą według precedencji - dziekanię ks. Woszczyński³3 i ks. Majowski (I72I-I733). Wspomniany już wyżej archidiakonat, który $\mathrm{z}$ czasem tracił znaczenie w kapitule, choć dawał znaczną rolę w administracji diecezji, piastował jedynie ks. M. Wąsowicz (I6I4-I6I9). Czwartą prałaturą była kustodia, a spośród biegonickich proboszczów godność tę posiadał jedynie ks. Bydłoniewicz ${ }^{74}$. Natomiast ks. Pałaszowski objął ostatnią chronologicznie utworzoną prałaturę, kancelariat (I729-I740). Kanonikami sądeckimi byli natomiast: księża Dzierzgowski, Machowicz, Majowski, Mroziński, S. Wąsowicz, Zagrodzki, zaś kanonikiem honorowym Pasiewicz. Kilku biegonickich proboszczów posiadało beneficja kanonickie w innych kapitułach. Najwięcej zgromadził ks. Pałaszowski, kanonik w kapitule św. Anny w Krakowie i kapitule św. Floriana, gdzie zresztą po jakimś czasie objął prałaturę kustosza, a także dziekan w kapitule kurzelowskiej. Dwie takie prebendy posiadał ks. Mroziński - kanonię w kolegiacie Wszystkich Świętych w Krakowie i kanonię w kapitule kolegiackiej w Tarnowie. Scholasterię w Wojniczu posiadał natomiast ks. Wargowski.

Pod koniec XV wieku sejm piotrkowski ograniczył prawo dostępu do kapituł plebejuszom, co potwierdzono w roku I505 (zamykając dostęp do prałatur) i I607 (blokując dostęp do kanonii) ${ }^{75}$. Ta uwaga ma znaczenie, jeśli weźmie się pod uwagę, że znaczna część biegonickich proboszczów wywodziła się z rodzin mieszczańskich. Jak widać, nie stosowano do końca tych zakazów, skoro udało im się jednak stosunkowo licznie obejmować prebendy prałackie i kanonickie w kilku kapitułach.

W ramach kapituły kolegiackiej w Nowym Sączu z czasem powołano urząd prokuratora kapituły (co nie wiązało się z uzyskaniem dodatkowej godności), odpowiedzialnego za sprawy

\footnotetext{
70 O randze tej kapituły np.: B. Przybyszewski, Kapituła krakowska za czasów kanonikatu Jana Długosza 14361480, w: Dlugossiana. Studia historyczne w pięćsetlecie śmierci Jana Dtugosza, red. S. Gawęda, Warszawa 1980, s. 25-84.

71 Elenchus [II], s. 3, 4. Kanonię krakowską w przypadku Wciankowicza potwierdza: F. Kiryk, Dzieje miasta..., dz. cyt., s. 100 .

72 Co ważne, S. Salaterski w swoim Katalogu prałatów i kanoników nie umieścił kilku nazwisk występujących w takich rolach w źródłach parafialnych.

73 Elenchus [II] nie podaje lat, w których ks. Woszczyński miałby być dziekanem kapituły, ks. Salaterski nie umieszcza go w wykazie dziekanów, zaś lata urzędowania Woszczyńskiego w Biegonicach pokrywają się z piastowaniem tej prałatury przez czterech prałatów.

74 S. Salaterski podaje różne daty - w treści swojego opracowania o kapitule sądeckiej wskazuje na daty $1657-$ 1670 (s. 81), zaś w dodatku - Katalogu prałatów i kanoników - na daty 1653-1658 (s. 303).

75 S. Kutrzeba, Historia ustroju Polski w zarysie. Korona, Warszawa 1949, s. 164-165; zob. także: S. Litak, Od reformacji do oświecenia. Kościół katolicki w Polsce nowożytnej, Lublin 1994.
} 
materialne wspólnoty duchownych. S. Salaterski w wykazie prokuratorów wskazał dwóch biegonickich proboszczów - ks. Majowskiego (w tym wypadku podał daty wykraczające poza okres jego życia) i ks. Mrozińskiego ${ }^{76}$.

Związki biegonickiej parafii z klasztorem klarysek nie ograniczały się do czasów Kingi i jej fundacyjnej roli. Zapewne z powodu bliskości Biegonic i Starego Sącza, może też z racji nieznanych już dzisiaj uzgodnień między fundatorką parafii i jej następczyniami na urzędzie przełożonej zakonu a biegonickimi proboszczami, ci ostatni często obejmowali funkcję spowiedników klarysek („,confesionarius Monialium seu poenitenciarius”77). Zadania te spełniali księża: Bydłoniewicz, Dzierzgowski, Machowicz, Majowski, Pałaszowski, Sitowski, Wargowski, S. Wąsowicz, Woszczyński i Zagrodzki. Natomiast ks. Adrian sprawował w nieokreślonych latach funkcję notariusza klarysek.

Warto wreszcie przyjrzeć się okolicznościom zakończenia posługi proboszczowskiej. Śmiercią naturalną zmarli Bydłoniewicz (I670), Dzierzgowski (I744), Habdański (I574), Jaroszowski (I653), Machowicz (I68I), Majowski (I733), Milanowski (I576), Sistowski (I6Io), Wargowski (I608), S. Wąsowicz (I59I), Wciankowicz (I624), Zagrodzki (I638). Jeden, ks. Sitowski, został zamordowany na plebanii biegonickiej przez nieznanego sprawcę w I775 roku. Czterech zostało usuniętych na mocy prawnych decyzji zwierzchników kościelnych Dąbrowski (I592), Mroziński (I769), Pasiewicz (I776), Sitowski (I76I). Czterech innych ustąpiło dobrowolnie - Maciej z Czorsztyna, Woszczyński, M. Wąsowicz i Pałaszowski, przy czym dwaj ostatni objęli później inne funkcje kościelne. Wreszcie jeden z biegonickich proboszczów, ks. Maciej, został usunięty z urzędu za bliżej nie określoną „crimen”, co w oczywisty sposób kojarzyć można z przestępstwem, choć, nie znając jego charakteru, nie można przesądzić, czy była to zbrodnia pospolita, czy może odstępstwo od praw Kościoła.

Zaledwie w przypadku pięciu proboszczów można stwierdzić miejsce pochówku. W Biegonicach pochowano na pewno ks. Adriana, którego płyta nagrobna usunięta z pierwotnego miejsca znajdowała się obok kościoła w Biegonicach jeszcze w I889 roku, gdy rysował ją Stanisław Wyspiański. W parafii pochowano również ks. Franciszka Pasiewicza, który zgodnie z austriackim prawem musiał na stałe przebywać w Biegonicach i, nie piastując innych funkcji, związał się z parafią do końca życia. W kolegiacie w Nowym Sączu pochowano dwóch prałatów kapituły, a także zasłużonych biegonickich proboszczów - ks. Bydłoniewicza i ks. Jaroszowskiego, zaś w kościele premonstratensów w Nowym Sączu zamordowanego ks. Sitowskiego. Można założyć, że w kolegiacie pochowano jeszcze innych, posiadających beneficja w kapitule biegonickich proboszczów: M. Wąsowicza, Majowskiego, Machowicza czy Wargowskiego.

Odszukana w źródłach grupa duchownych sprawujących urząd proboszcza w Biegonicach między XIII a XVIII wiekiem okazała się niemała. Nie kończyli swych karier biskupimi godnościami, biorąc jednak pod uwagę, że Biegonice to mała, zaledwie dwuwioskowa parafia, jej duchowni włodarze osiągnęli przecież niemało w hierarchii Kościoła na Sądecczyźnie. Byli wśród nich ludzie nietuzinkowi, dobrze wykształceni i wysmakowani kulturowo. A to tylko mała próba, oparta na jednej z wielu lokalnych parafii, opisania środowiska duchownych w tamtym czasie.

\footnotetext{
76 S. Salaterski, Kolegiata..., dz. cyt., s. 85

77 APB, Elenchus II, s. 4.
} 


\section{Pastors of St. Lawrence parish in Biegonice in the Old-Polish period: A contribution to the history of the clergy of the Sącz region}

\section{Abstract}

The article discusses issues related to the history of St. Lawrence parish in Biegonice in the Old-Polish period, through the prism of the clergy holding the office of parish priest. Thanks to a thorough scientific query in numerous archives, it was possible to identify a total of 29 clergymen holding the office of parson in Biegonice. Through thorough research, some additional data were obtained about some of them, thanks to which the community of the pastors was analysed in terms of their geographical and social origin, education, and other functions held in the Church - prelates, canons, court officials and confessors for the convent of the Poor Clares in Stary Sącz. The conclusions will permit a better comprehension of the conditions related to the clergy in the broadly understood area of the Sacz region in the Old-Polish period.

Key words: Sącz region, Catholic Church, Biegonice, parish priest, right of patronage

\section{BIBLIOGRAFIA}

\section{Archiwum Diecezjalne w Tarnowie [ADT]}

Akta lokalne Nowy Sącz-Biegonice [ALNSB]

Inventarium ecclesiae parochialis s. Laurentii Bieganicensis anno Domini I669 [regest].

Pismo konsystorza biskupiego w Tarnowie z 6 stycznia I879 r.

Księgi parafialne

Cathalogus baptizatorum in ecclesia Biegonicensi ad anno MDCLIII, [rps], [npg], [KCh I653].

Cathalogus Baptisatorum in Ecclesia Parochiali Biegonicensi [od I7 czerwca I68I], [rps],

[npg], [KCh I68I].

Cathalogus sine Menica Matrimonium Sanctum Contrahentium [...] [od I7 czerwca I68I],

[rps], [npg.], [KŚ I68I].

Księga inwentarzy kościelnych [KIK].

[Księga ślubów, bez tytułu, dołączona do KCh I653], [rps], [npg], [KŚ I653].

Liber Baptisatorum in Ecclesia Parochiali Biegonicensi ab I738, [rps], [npg], [KCh I738].

Liber Connotans Defunctos in Villa Bieganice [od I738], [rps], [npg], [KZ I738].

Liber metrices copulatorum [I738], [rps], [npg], [KŚ I738].

\section{Archiwum Kurii Metropolitalnej w Krakowie [AKMK]}

AAdm., t. 24.

AEp., t. 54, t. IOO.

AOff., t. I06, t. I07, t. III, t. II6, t. I62, t. I63, t. I7I, t. I93.

AVisCap., t. 39, t. 49, t. 60.

Decriptio ecclesiarum parochialium et beneficiorum consistentium cum circumctantiis in

Tabela Normali ab Excelso Gubernio sub die 2da septembris anni elapsi porrecta spe-

cificatis facta, Anno Domini 1776.

LOrd., t. 4, t. 6, t. 7, t. 8, t. 9 .

Tabele Załuskiego, t. I2, nr 3I, 32, 54. 


\section{BPAN}

Rps I643.

\section{Archiwum Parafialne w Biegonicach [APB]}

Dowody y obrona dla Informatyey Przewielebney Mości Panny Xienżney y wszystkiego Świątobliwego Zgromadzenia $w$ tym iako dway chałupnicy Plebanszczy do żadnych podatków Bieganskiey Gromady niepowinni się przykładać, [dokument sprzed 1670 roku w odpisie z I686 r.], [rps].

Elenchus omnium parochorum qui penes Ecclesiam Bieganicensen ab anno I59o usque ad novissima tempora, [Elenchus I].

Elenchus sacerdotum qui penes Ecclesiam Bieganicensen ab anno [brak w rękopisie] usque ad novissima tempora, [Elenchus II].

Inventarium Ecclesiae Biganicensis [I739].

Inventarium Parochialis Biegunicensis Tituli S. Laurentii Dioecesis Cracoviensis Decanatus Sandecensis [...] in circulo Velicensis Districtu Sandecensi [brak daty, zapewne ok. I775]. Inventarium vasorum, praetiosorum et apparamentorum Ecclesiae Parochialis in pago Biegonice, I7 julii I785.

Obmyślenie dla organisty sustencyi, [I752 r.], [rps].

Pismo O. Modesta Jana Pasiecznika do proboszcza w Biegonicach z I2 grudnia 1977 r.

Pro memoria notatur [rps].

Relacja ks. Sitowskiego [bez daty, II poł. XVIII w.], [rps].

\section{Źródla drukowane}

Ioannis Dlugosz senioris canonici Cracoviensis Liber beneficiorum dioecesis Cracoviensis. Opera omnia, vol. II, cura A. Przezdziecki, Cracoviae I864.

Listy Annibala z Kapui, arcybiskupa neapolitańskiego, nuncyusza w Polsce, o bezkrólewiu po Stefanie Batorym i pierwszych latach panowania Zygmunta III, do wyjścia arcyksięcia Maxymiliana z niewoli. Z rękopisu biblioteki Brancacciana w Neapolu wybrat, przettumaczył z języka włoskiego na polski $i$ wydat Alexander Przeździecki, Warszawa I852.

Monumenta Poloniae Vaticana, t. I: Acta Camerae Apostolicae, vol. I: I207-I344, red. J. Ptaśnik, Cracoviae I9I3.

Stanko P., Najstarsze inwentarze kościoła parafialnego w Nowym Saczu-Biegonicach z XVI-XVII wieku, „Almanach Sądecki”, I9/20Io, nr I/2(70/7I), s. 3-23.

\section{Opracowania}

Bazielich W., Materiaty do historii szpitala, kościoła i prepozytury św. Krzyża w Starym Saczu, „Nasza Przeszłość” [dalej: NP], I96I, t. I4, s. 203-247.

Bazielich W., Parafialni proboszczowie starosadeccy, NP, 1959, t. 9, s. 9I-I55.

Bazielich W., Resztki „Biblioteki parafialnej” w Starym Saczu, „Roczniki Biblioteczne”, I962, t. 6, s. I47-I70.

Gąsiorowska P., Konwent Klarysek krakowskich do końca XVIII wieku. Studium prozopograficzne, Kraków 2015.

Herzig F., Katedra niegdyś kolegiata w Tarnowie wraz z krótka wzmianką o innych kościolach w Tarnowie, Tarnów 1900.

Jujeczka S., Duchowni średniowiecznej Legnicy. Studium prozopograficzne, Legnica 2006. 
Jureczko A., W'́redniowieczu, w: Podegrodzie i gmina podegrodzka. Zarys dziejów, red. F. Kiryk, Kraków 20I4, s. 87-I34.

Kiryk F., Dzieje miasta w okresie staropolskim, w: Historia Starego Sacza od czasów najdawniejszych do 1939 roku, red. H. Barycz, Nowy Sącz 2007, s. 49-I28.

Kiryk F., Sądecka Pani, „Rocznik Sądecki”, I999, t. 27, s. 9-20.

Kracik J., Vix venerabilies. Z dziejów społecznych niższego kleru parafialnego $w$ archidiakonacie krakowskim w XVII-XVIII wieku, Kraków 1982.

Krajniak R., Duchowieństwo kapituly katedralnej w Chetmży do I466 roku, Toruń 2013.

Kumor B., Archidiakonat sądecki. Opracowanie materiałów źródłowych do Atlasu Historycznego Kościoła w Polsce, „Archiwa, Biblioteki i Muzea Kościelne”, I964, t. 8, s. 27I-304.

Kumor B., Dzieje diecezji krakowskiej do roku I795, t. 4, Kraków 2002.

Kumor B., Parafia i życie kościelne, w: Dzieje miasta Nowego Sacza, red. F. Kiryk, t. 3, Warszawa-Kraków I996, s. I87-202.

Kutrzeba S., Historia ustroju Polski w zarysie. Korona, Warszawa 1949.

Litak S., Od reformacji do oświecenia. Kościół katolicki w Polsce nowożytnej, Lublin I994.

Przybyszewski B., Kapituła krakowska za czasów kanonikatu Jana Długosza I436-I480, w: Dlugossiana. Studia historyczne w pięćsetlecie śmierci Jana Długosza, red. S. Gawęda, Warszawa I980, s. 25-84.

Rajman J., Osadnictwo okolic Nowego Sącza i kształtowanie się strefy podmiejskiej średniowiecznego miasta (XIII-XV w.), w: Dzieje miasta Nowego Sacza, red. F. Kiryk, t. I, Warszawa-Kraków 1992, s. 53-84.

Salaterski S., Kolegiata i kapituła św. Małgorzaty P.M. w Nowym Saczu (I448-I79I), Nowy Sącz 1997.

Sikora F., Biegonice, w: Słownik Historyczno-Geograficzny Województwa Krakowskiego w średniowieczu, oprac. Z. Leszczyńska-Skrętowa, F. Sikora, cz. I, z. I: A-Borek, Wrocław-Warszawa-Kraków-Gdańsk i980, s. 89-90.

Skowron R., Nuncjusz i ambasador. Korespondencja Annibala z Capui z Guillenem de San Clementem (I586-I59I), w: Od Kijowa do Rzymu. Z dziejów stosunków Rzeczypospolitej ze Stolica Apostolska i Ukraina, red. M.R. Drozdowski, W. Walczak, K. Wiszowata-Walczak, Białystok 20I2, s. 453-467.

Sumowski M., Duchowni w średniowiecznym Toruniu. Studium prozopograficzne, Toruń 2012.

Szczepaniak J., Duchowieństwo diecezji krakowskiej w XVIII wieku. Studium prozopograficzne, Kraków 2010.

Szczepaniak J., Katalog duchowieństwa diecezjalnego zestawiony na podstawie krakowskich ksiag święceń (I646-I789), t. 2: J-M, Kraków 2008.

Szczepaniak J., Odtworzone katalogi seminariów diecezji krakowskiej (XVII-XVIII w.), Kraków 2005.

Szymański J., Kapituła kolegiacka w Wojniczu I465-I786, Lublin 1962.

Wróblewski S., Początki chrześcijaństwa w Sadecczyźnie w świetle dyskusji o chrystianizacji Małopolski w IX-X wieku, ,Rocznik Sądecki”, 20I7, t. 45, s. 33-47.

Zygmunt D., Historia parafii p.w. św. Elżbiety w Starym Saczu od XIII w. do I786 r., [mps], Kraków 2009. 